\title{
Robert Wolny
}

Uniwersytet Ekonomiczny w Katowicach

e-mail: robert.wolny@ue.katowice.pl

\section{PREFERENCJE I POSTAWY KONSUMENTÓW WOBEC KINA I FILMU}

\section{PREFERENCES AND CONSUMER ATTITUDES TO THE CINEMA AND FILMS}

DOI: $10.15611 /$ pn.2018.526.26

JEL Classification: M31, D12

Streszczenie: Postępowanie konsumenta na rynku kinematografii jest efektem jego upodobań i preferencji. Konieczność ciągłego badania preferencji, potrzeb i postaw konsumentów wynika ze zmian (ilościowych i jakościowych) zachodzących na rynku. Problem preferencji i postaw konsumentów na rynku kinematografii jest o tyle złożony, że dotyczy zarówno filmu, jak i kina, w którym konsument ogląda dany film. Celem artykułu jest próba wskazania możliwości wykorzystania skal nominalnych i porządkowych do badania preferencji i postaw konsumentów wobec kina i filmu. W artykule wykorzystano własne wyniki badań bezpośrednich. Wyniki uzyskane z wykorzystaniem skali nominalnej przedstawiają postawy konsumentów co do kina jako sposobu spędzania wolnego czasu, postawy wobec zachowania się innych osób w kinie oraz preferencje co do wyboru filmu. Wyniki uzyskane z wykorzystaniem skali porządkowej prezentują ocenę funkcjonowania kin oraz wyświetlanych produkcji filmowych.

Slowa kluczowe: preferencje, postawy, konsument, kino.

Summary: Attitudes and preferences influence consumer behavior on the cinema market. Consumers' preferences and attitudes on the cinema market relate to film and cinema. The objective of the article is to attempt to indicate the possibility of using nominal and ordinal scales to survey consumer preferences and attitudes towards cinema and film. The selected results of field research studies conducted for Polish Film Institute and concerning the behaviours of cinema viewers were used in the article. The results obtained using the nominal scale show the attitudes of consumers towards to the cinema, attitudes towards to behavior of other people in the cinema and preferences towards to the choice of the film. The results obtained with the use of the ordinal order present an assessment of the functioning of cinemas and displayed film productions.

Keywords: preferences, attitudes, consumer, cinema. 


\section{Wstęp}

Preferencje i postawy konsumentów badane są w celu poznania systemu ocen odzwierciedlających ich potrzeby i upodobania. Struktura preferencji odzwierciedla hierarchiczną strukturę możliwości wyboru - przedkładania (np. danego kina nad inne kino, danego filmu nad inny film). Potrzeba badania postaw i preferencji wynika ze stale zmieniającego się rynku kinematografii. Zmianie ulega zarówno podaż, w tym coraz to nowe produkcje filmowe wchodzące na ekrany kin (także coraz bogatsza oferta filmów polskich), jak i oferta kin (związana między innymi z komfortem oglądania filmu). Film jako produkt niematerialny i niezestandaryzowany stanowi problem do jego oceny. Na ocenę filmu, a przynajmniej warunków jego odbioru, duży wpływ ma miejsce jego oglądania. Pomiar preferencji i postaw zarówno wobec filmu, jak i kina z pozoru nie wydaje się skomplikowany. W praktyce prowadzenia badań napotyka się jednak problemy w doborze skal, poborze informacji, jak również analizie wyników.

Celem artykułu jest próba wskazania możliwości wykorzystania skal nominalnych i porządkowych do badania preferencji i postaw konsumentów wobec kina i filmu. W artykule przedstawiono wyniki badań field research. Źródła pierwotne stanowią dane ilościowe zebrane w 2015 roku techniką wywiadu bezpośredniego. Podmiotem badania byli konsumenci na rynku usług kinowych ${ }^{1}$.

\section{Postawy i preferencje konsumentów}

W marketingu problem postaw konsumentów stanowi istotny nurt badań nad zachowaniami konsumentów. Złożony i wielowymiarowy charakter postaw wymaga szeregu rozstrzygnięć natury terminologicznej. W literaturze można znaleźć wiele definicji postaw pochodzących $\mathrm{z}$ różnych dyscyplin i szkół naukowych. Postawą człowieka wobec przedmiotu jest „ogół względnie trwałych dyspozycji do oceniania tego przedmiotu i emocjonalnego nań reagowania oraz ewentualnie towarzyszących tym emocjonalno-oceniającym dyspozycjom względnie trwałych przekonań o naturze i własnościach tego przedmiotu i względnie trwałych dyspozycji do zachowania się wobec tego przedmiotu" [Nowak (red.) 1973]. Postawa jest trwałą oceną ludzi, obiektów, idei, sytuacji itp. Jeśli postawy są oceną, tzn. że są one pozytywną lub negatywną reakcją na coś [Aronson, Wilson, Akert 2000]. Postawa to także ,pewien względnie stały stosunek emocjonalny lub oceniający do przedmiotu bądź też dyspozycja do występowania takiego stosunku, wyrażająca się w kategoriach pozytyw-

${ }^{1}$ Badania przeprowadzono na losowo dobranej próbie badawczej 2048 osób uczęszczających do kina, mieszkających w 16 województwach (z podziałem na widzów kin studyjnych oraz mini- i multipleksów). Badania zostały przeprowadzone przez Centrum Badań i Transferu Wiedzy Uniwersytetu Ekonomicznego w Katowicach dla Polskiego Instytutu Sztuki Filmowej w Warszawie w ramach projektu „Widz kinowy w Polsce”. 
nych, negatywnych lub neutralnych" [Mika 1984]. Postawę można również zdefiniować jako: „umysłowy i nerwowy stan gotowości organizmu, ukształtowany przez doświadczenie oraz kierujący i organizujący reakcje jednostki na dane przedmioty i w określonych sytuacjach, z którymi ten stan jest związany" [Krasiński, Piasny, Szulce 1984]. Postawy odnoszą się więc do przedmiotów i zjawisk z naszego otoczenia, a zachowanie się konsumenta jest właśnie uzewnętrznieniem się jego postaw.

W definiowaniu terminu postawa obserwuje się pewne różnice. W podejściu behawiorystycznym postawa określana jest jako pewnego rodzaju dyspozycje do zachowania się w określony sposób. W koncepcji socjologicznej postawa to określony, względnie trwały stosunek emocjonalny lub oceniający do przedmiotu. W koncepcji psychologicznej postawa to nie tylko określone zachowanie czy stosunek emocjonalny lub oceniający wobec danego przedmiotu, ale także odnoszące się do niego elementy poznawcze [Rudnicki 2004].

Postawy mogą być wynikiem własnych doświadczeń i działań człowieka lub mogą zostać przyswojone od otoczenia w wyniku na przykład obserwacji. To właśnie otoczenie konsumenta kształtuje większość jego postaw. Wiele postaw konsument nabywa w domu. Postawy są również wynikiem tego, że konsument należy do danej grupy społecznej (między innymi zwyczaje i obyczaje panujące w obrębie danej grupy są determinantami postaw). Przyjmowanie takich lub innych postaw łączy się z kształtowaniem określonych ideologii, poglądów, przekonań, odczuć czy uprzedzeń oraz przyczynia się do tego, że konsument przedkłada dane wartości nad inne. Co ważne, werbalnym wyrazem postaw są opinie, a ich badanie może pomóc w ocenie wpływu postaw na zachowania konsumentów.

Postawę można traktować jako strukturę złożoną z wielu poznawalnych elementów. Wyróżnia się następujące składniki (komponenty) postaw [Karcz, Kędzior 1999]:

- składnik afektywny (emocjonalny), tj. uczucia w stosunku do przedmiotu postawy - przejawia się w upodobaniach i preferencjach,

- składnik poznawczy, tj. wiedza i przekonania dotyczące przedmiotu postawy,

- składnik behawioralny (motywacyjny), tj. zachowanie intencjonalne bądź zachowanie realne wobec przedmiotu postawy.

W nawiązaniu do komponentów postaw warto zwrócić uwagę na ich własności [Churchill 2002]:

- postawa jest predyspozycją do reagowania na obiekt, a nie faktycznym zachowaniem wobec tego obiektu;

- postawa jest trwała w czasie;

- postawa jest zmienną uśpioną, która powoduje konsekwencje w zachowaniu werbalnym lub fizycznym;

- postawie przysługuje prymat ukierunkowania (związana jest z preferencjami odnoszącymi się do ocen obiektu albo odczuć wobec obiektu). 
Postawy konsumentów wobec kina/filmu to kategoria reprezentująca idee, przekonania czy preferencje widza w odniesieniu do konkretnego kina (rozumianego jako miejsce wyświetlania filmu) lub gatunku filmowego oraz danego filmu. Należy zwrócić uwagę, że kształtowanie postaw wobec kina może być uwarunkowane postawą wobec filmu (widz kształtuje swoje postawy wobec kina na podstawie repertuaru prezentowanego w danej placówce kinowej), ale również postawą wobec filmu może być „wzmocniona” postawa wobec kina (dyskomfort oglądania filmu doświadczony w danej placówce kinowej może przekładać się na postawę wobec filmu).

Afektywny składnik postaw konsumentów może przybierać postać preferencji. Preferować znaczy tyle co: „woleć, przedkładać” [O’Shaughnessy 1994]. Preferencje konsumpcyjne to subiektywne oceny, którymi kieruje się jednostka dokonująca wyborów konsumpcyjnych. Preferencje są relacją binarną, odnoszoną do wektorów opisujących wielowymiarowe obiekty, tzw. profile dóbr lub usług, których zbiory tworzą tzw. koszyki towarów lub plany konsumpcji [Bąk 2013]. Preferencje przejawiają się wówczas, gdy konsument wybiera jedną z wielu możliwości. Co ważne, oprócz charakteru preferencji (wewnętrzne, zewnętrzne), istotną ich własnością jest zmienność w czasie oraz zmienność pod wpływem nowych informacji. Pomiar preferencji wykorzystywany jest w ekonomii do kwantyfikacji użyteczności.

Użyteczność określana jest jako satysfakcja, poczucie zaspokojenia potrzeby, które uzyskuje się z konsumpcji dóbr i/lub usług [Wiszniewski 1997]. Użyteczność jest subiektywną miarą stopnia zadowolenia konsumenta. Jest to indywidualne odczucie psychiczne, które może być różne u poszczególnych konsumentów (co wynika z uwarunkowań psychologicznych i socjologicznych oraz przyjętego systemu wartości konsumentów). Użyteczność można rozpatrywać jako pewną konstrukcję analityczną, wykorzystywaną w celu wyjaśnienia sposobu, w jaki racjonalnie zachowujący się konsumenci dzielą swoje ograniczone dochody pomiędzy produkty, które przynoszą im największe zadowolenie czy też są dla nich najbardziej użyteczne [Marciniak (red.) 2001]. Oznacza to, że konsumenci maksymalizują funkcję użyteczności [Oleksiak, Białek 2008; Nasiłowski 2006; Buczyńska 2007]. Preferencje te można zilustrować za pomocą krzywych obojętności o różnym stopniu nachylenia i ograniczeniu analizy do dwóch produktów substytucyjnych. Krzywe obojętności przedstawiają wszystkie kombinacje produktów, które dla konsumenta są obojętne, tzn. że dostarczają takiej samej użyteczności całkowitej [Woś, Tachocka, Kasperek-Hoppe 2011; Begg, Fischer, Dornbusch 2007].

Na rynku usług kinowych postać dwóch produktów substytucyjnych mogą przybrać kina wyświetlające ten sam film. Warunki, jakie kina stworzą konsumentom do oglądania tego samego filmu (związane z dotarciem do kina, wystrojem kina, infrastrukturą techniczną, jakością obrazu i dźwięku czy ofertą gastronomiczną), będą miały wpływ na zadowolenie konsumentów oraz na kształtowanie się preferencji konsumentów przy wyborze miejsca oglądania filmu w przyszłości. 


\subsection{Pomiar postaw i preferencji}

W badaniach poszczególnych komponentów postaw konieczne staje się ustalenie zbioru obserwowalnych wskaźników poddawanych pomiarowi. Charakter komponentów postaw determinuje rodzaj stosowanych w badaniach metod i narzędzi pomiarowych [Karcz, Kędzior 1999]. Do pomiaru postaw stosuje się najczęściej pierwotne (bezpośrednie) źródła informacji, wykorzystując zwykle metody wywiadu, metody ankietowe i metody projekcyjne. Badania postaw polegają na analizie obserwowalnych reakcji respondentów na określone sytuacje. Reakcje te mogą mieć charakter słownych wypowiedzi i opinii, lecz mogą mieć również charakter zachowań niewerbalnych, będących poza kontrolą badanych osób [Sagan 2004]. Postawy przyjmują wartości mieszczące się w przedziale: ,postawa skrajnie pozytywna-postawa zdecydowanie negatywna”. Można je, dzięki temu, mierzyć przy wykorzystaniu różnych skal, w tym nominalnych i porządkowych.

Badania preferencji konsumentów prowadzone są zarówno w oparciu o źródła wtórne, jak i pierwotne. Te dwa źródła informacji o preferencjach pozwalają na wyróżnienie metod analizy preferencji ujawnionych oraz metod analizy preferencji wyrażonych [Bąk 2013]. Preferencje ujawnione stanowią odwzorowanie rzeczywistych decyzji rynkowych konsumentów. Preferencje wyrażone odnoszą się do deklarowanych (hipotetycznych) wyborów rynkowych konsumentów. Znajdują tutaj zastosowanie metody reprezentujące podejście kompozycyjne, dekompozycyjne, mieszane i mikroekonometryczne modele zmiennych jakościowych (obserwacji dyskretnych) [Bąk 2013].

Problem pomiaru postaw i preferencji konsumentów dotyczących kina i filmu jest złożony. W zależności od przyjętych celów badania w konstrukcji narzędzi pomiarowych można wykorzystać skale metryczne i niemetryczne [Oppenheim 1992; Kowal 1998]. W dalszej części artykułu zostanie dokonana krótka charakterystyka tylko wybranych skal (nominalnej i porządkowej) zastosowanych w badaniach bezpośrednich preferencji i postaw widzów dotyczących kina i filmu.

Skala nominalna (stosowana jest do pomiaru cech jakościowych) umożliwia zupełną i rozłączną klasyfikację zbioru wyników. W wyniku pomiaru otrzymuje się zbiór obserwacji, na który składa się $n_{1}$ obiektów typu $1, n_{2}$ obiektów typu $2, \ldots$ do $n_{z}$ obiektów typu $z$. Stosując skalę nominalną, nie ma możliwości uporządkowania poszczególnych obserwowanych cech w kolejności wartościującej. Do badania postaw i preferencji na poziomie nominalnym stosuje się skale: dychotomiczne, wielokategorialne oraz pozycyjne [Sagan 2004].

Skala porządkowa umożliwia przyporządkowanie jednostek według stopnia natężenia badanej cechy. Pozwala uporządkować jednostki zbiorowości w kolejności wielkościowej oraz umożliwia określenie stopnia natężenia posiadania danej cechy w zbiorowości. W pomiarze na skali porządkowej nie można jednak określić dystansu (różnicy) pomiędzy jednostkami należącymi do różnych grup klasyfikacji [Sagan 2016]. Do badania postaw i preferencji na poziomie porządkowym stosuje się mię- 
dzy innymi skale: rang, porównań parami, semantyczną, Likerta oraz Guttmana [Sagan 2004].

$\mathrm{W}$ badaniach postaw korzysta się także $\mathrm{z}$ wyższego poziomu pomiaru (przedziałowego i stosunkowego), wykorzystując do tego celu skalę Thurstone'a oraz skalę stałej sumy [Sagan 2004]. Należy również zaznaczyć, że przy badaniu postaw i preferencji wyróżnia się w literaturze także podział na: skale (szacunkowe i rangowe) oraz modele (np. ELM, kategoryzacyjny, spójności postaw, struktur poznawczych, reakcji poznawczych, efektu ekspozycji) [Kaczmarczyk 2007; Sagan 2004].

\section{Wyniki badań}

Na postawy i preferencje konsumentów wobec kina i filmu wpływ może mieć wiele czynników. Kino, jako miejsce odbioru produktu kulturalnego, pośrednio wpływa na ocenę samego filmu. Bezpośrednie oddziaływanie na odbiór filmu przez widza będzie miała jakość obrazu i dźwięku. Pośrednio do takich czynników można zaliczyć wygodę foteli czy klimatyzację. Znaczenie tych czy innych czynników zależy od indywidulanych upodobań każdego konsumenta i w szerszym kontekście wpływa na jego wybory rynkowe. Na postawy i preferencje widzów kinowych duży wpływ ma ich przygotowanie i predyspozycje do odbioru kultury (w tym również oczekiwanie głębokich doznań artystycznych lub nieskomplikowanej rozrywki) [Sobocińska 2015]. W dalszej części artykułu zostaną zaprezentowane tylko wybrane wyniki badań, dotyczące preferencji i postaw konsumentów - widzów wobec kina i filmu [Centrum Badań i Transferu Wiedzy 2015].

W przeprowadzonych badaniach dokonano pomiaru postaw i preferencji na poziomie nominalnym i porządkowym. Pomiar na skali nominalnej i porządkowej ogranicza dopuszczalne operacje matematyczne. Wybrane wyniki badań zaprezentowano zatem w postaci frakcji oraz graficznie.

Z badań wynika, że respondenci w większości wybierają się do kina, gdy chcą zobaczyć konkretny film. Co trzeci badany uznaje, że wyjście do kina to tylko sposób spędzania wolnego czasu (nieważne, na jaki film, ważne jest wyjście do kina). Odsetek osób wybierających konkretny film nieznacznie rośnie wraz ze wzrostem wieku respondentów. Powodem wyjścia do kina jest chęć przeżycia pozytywnych emocji związanych z filmem, przyjemności związanej z wrażeniami wywoływanymi przez film oraz realizowania własnych zainteresowań. Ponad połowa badanych (niezależnie od płci i wieku) deklaruje, że uczęszcza do różnych kin, w zależności od repertuaru. W próbie ogółem niemal tyle samo respondentów deklaruje, że wybierze się na film zagraniczny z polskim dubbingiem, co z napisami. Film zagraniczny z polskim dubbingiem wybierze jednak większość mężczyzn oraz badanych w wieku do 24 lat i powyżej 30 lat. W grupie badanych powyżej 50. roku życia jest to ponad $70 \%$. Ponad $40 \%$ badanych w wieku do 24 lat wyjdzie z kina w trakcie seansu, jeśli film nie przypadnie im do gustu. Ponad połowie badanych w wieku 40-49 lat i niemal połowie badanych w wieku do 39 lat i powyżej 50 lat przeszkadza spoży- 
wanie posiłków podczas seansu. Konsumpcja podczas seansu staje się coraz powszechniejsza wśród widzów, a co za tym idzie, częściej akceptują takie zachowanie wśród innych (szczególnie gdy zachowują się podobnie) (tab. 1).

Tabela 1. Postawy i preferencje widzów kinowych według płci i wieku (w \%)

\begin{tabular}{|l|c|c|c|c|c|c|c|c|}
\hline \multirow{2}{*}{ Wyszczególnienie } & \multirow{2}{*}{ Ogółem } & \multicolumn{6}{c|}{ Respondenci według } \\
\cline { 5 - 10 } & & kobiety & mężczyźni & do 24 & $25-29$ & $30-39$ & $40-49$ & $\begin{array}{c}\text { płci } \\
\text { i więcej }\end{array}$ \\
\cline { 5 - 10 } & & & & & & & & \\
\hline $\begin{array}{l}\text { Chodzę do kina, ponieważ chcę } \\
\text { obejrzeć konkretny film }\end{array}$ & 65,8 & 65,0 & 66,8 & 68,0 & 64,0 & 62,6 & 72,8 & 73,4 \\
\hline $\begin{array}{l}\text { Wyjście do kina jest dla mnie } \\
\text { sposobem spędzenia wolnego czasu }\end{array}$ & 34,2 & 35,0 & 33,2 & 32,0 & 36,0 & 37,4 & 27,2 & 26,6 \\
\hline $\begin{array}{l}\text { Chodzę do różnych kin w } \\
\text { zależności od repertuaru }\end{array}$ & 60,4 & 59,6 & 61,3 & 57,9 & 59,6 & 60,4 & 66,6 & 56,2 \\
\hline $\begin{array}{l}\text { Chodzę zawsze do tego samego } \\
\text { kina }\end{array}$ & 39,6 & 40,4 & 38,7 & 42,1 & 40,4 & 39,6 & 33,4 & 43,8 \\
\hline $\begin{array}{l}\text { Chętniej wybiorę się na film } \\
\text { zagraniczny z polskim dubbingiem }\end{array}$ & 50,8 & 53,3 & 47,7 & 58,1 & 43,8 & 54,0 & 56,2 & 72,2 \\
\hline $\begin{array}{l}\text { Chętniej wybiorę się na film } \\
\text { zagraniczny z polskimi napisami }\end{array}$ & 49,2 & 46,7 & 52,3 & 41,9 & 56,2 & 46,0 & 43,8 & 27,8 \\
\hline $\begin{array}{l}\text { Siedzę do końca seansu, nawet jeśli } \\
\text { mi się film nie podoba }\end{array}$ & 69,1 & 69,5 & 68,7 & 59,4 & 63,3 & 64,5 & 62,4 & 72,8 \\
\hline $\begin{array}{l}\text { Wychodzę z seansu w środku } \\
\text { filmu, jeśli mi się film nie podoba }\end{array}$ & 30,9 & 30,5 & 31,3 & 40,6 & 36,7 & 35,5 & 37,6 & 27,2 \\
\hline $\begin{array}{l}\text { Nie przeszkadza mi spożywanie } \\
\text { posiłków podczas seansu }\end{array}$ & 61,8 & 61,0 & 62,8 & 59,1 & 60,1 & 55,6 & 49,3 & 50,9 \\
\hline $\begin{array}{l}\text { Przeszkadza mi spożywanie } \\
\text { posiłków podczas seansu }\end{array}$ & 38,2 & 39,0 & 37,2 & 40,9 & 39,9 & 44,4 & 50,7 & 49,1 \\
\hline
\end{tabular}

Źródło: badania własne.

Wyniki pomiaru na skali nominalnej można przedstawić w postaci graficznej. $\mathrm{Z}$ badań wynika, że miejsce zamieszkania respondentów różnicuje preferencje dotyczące wyboru kina, jako miejsca oglądania filmu, oraz filmu zagranicznego, na jaki wybiorą się respondenci (z polskim dubbingiem lub z napisami). Więcej respondentów z województw: lubuskiego, kujawsko-pomorskiego, opolskiego i świętokrzyskiego chodzi zawsze do tego samego kina. Więcej badanych z pozostałych województw wybiera kino $\mathrm{w}$ zależności od repertuaru. $\mathrm{Z}$ kolei więcej badanych z województw: warmińsko-mazurskiego, lubuskiego, mazowieckiego, śląskiego, małopolskiego i podkarpackiego chętniej wybierze się na film zagraniczny z polskimi napisami. W pozostałych województwach więcej badanych chętniej wybierze się na film zagraniczny z polskim dubbingiem (rys. 1).

$\mathrm{W}$ badaniach bezpośrednich, na skali porządkowej, respondenci dokonali oceny funkcjonowania kin w Polsce. Ocena została przeprowadzona w oparciu o ocenę 14 charakterystyk kina (na siedmiostopniowej skali Likerta, która została zredukowana 
do skali pięciostopniowej). Respondenci wysoko ocenili funkcjonowanie kin, do których uczęszczają. Najwyżej badani ocenili jakość obrazu, jakość dźwięku, godziny otwarcia, a najniżej liczbę reklam produktów przed seansem, karty członkowskie/ klubowe oraz promocje stosowane przez kino (tab. 2).
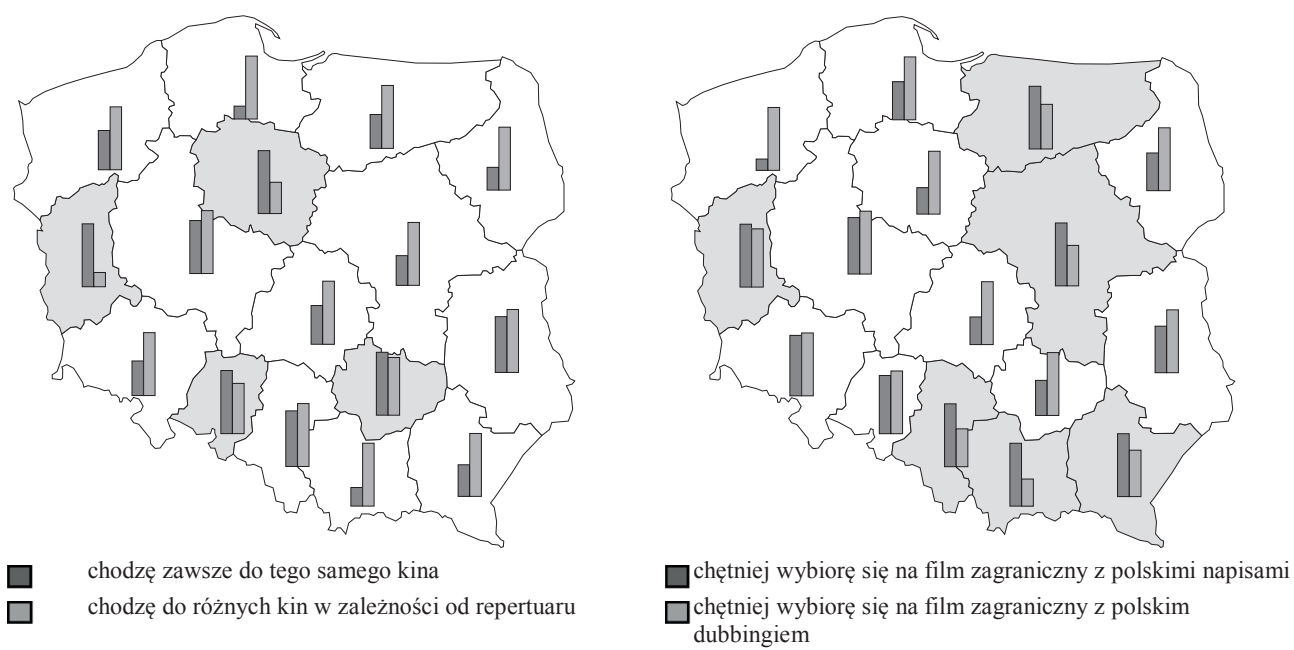

Rys. 1. Preferencje dotyczące wyboru kina oraz rodzaju filmu według miejsca zamieszkania respondentów - pomiar nominalny

Źródło: opracowanie własne.

Tabela 2. Ocena funkcjonowania kin (w \%) - pomiar porządkowy

\begin{tabular}{|l|r|r|c|c|c|}
\hline \multirow{2}{*}{ Wyszczególnienie } & \multicolumn{5}{c|}{ Ocena } \\
\cline { 2 - 6 } & 1 & 2 & 3 & 4 & 5 \\
\hline Jakość obrazu & 1,6 & 2,8 & 9,4 & 20,0 & 66,2 \\
\hline Jakość dźwięku & 1,7 & 2,5 & 8,7 & 21,5 & 65,6 \\
\hline Godziny otwarcia & 1,7 & 2,8 & 9,2 & 20,7 & 65,6 \\
\hline Lokalizacja & 2,2 & 5,5 & 10,4 & 21,2 & 60,7 \\
\hline Klimatyzacja & 3,3 & 3,3 & 11,1 & 23,6 & 58,7 \\
\hline Wystrój/klimat wnętrz kina & 2,4 & 3,7 & 11,4 & 24,1 & 58,4 \\
\hline Przestrzeń między rzędami & 3,4 & 4,5 & 12,7 & 26,4 & 53,0 \\
\hline Częstotliwość projekcji filmów, repertuar & 3,0 & 5,1 & 12,4 & 26,7 & 52,8 \\
\hline Możliwość dotarcia komunikacją miejską & 5,3 & 5,8 & 12,8 & 23,6 & 52,5 \\
\hline Dostępność parkingu & 7,5 & 7,8 & 14,2 & 20,9 & 49,6 \\
\hline Oferta gastronomiczna & 7,5 & 7,5 & 17,6 & 24,4 & 43,0 \\
\hline Promocje stosowane przez kino & 9,2 & 6,8 & 16,7 & 25,4 & 41,9 \\
\hline Karty członkowskie, klubowe & 12,7 & 9,9 & 18,4 & 23,2 & 35,8 \\
\hline Liczba reklam produktów przed seansem & 21,0 & 12,2 & 18,0 & 21,0 & 27,8 \\
\hline
\end{tabular}

Źródło: badania własne. 
Tabela 3. Ocena filmów zagranicznych i polskich w repertuarze kin (w \%) - pomiar porządkowy

\begin{tabular}{|l|c|c|c|c|c|c|c|c|c|c|}
\hline \multirow{2}{*}{ Wyszczególnienie } & \multicolumn{3}{|c|}{ Ocena filmów zagranicznych } & \multicolumn{5}{c|}{ Ocena filmów polskich } \\
\cline { 2 - 13 } & 1 & 2 & 3 & 4 & 5 & 1 & 2 & 3 & 4 & 5 \\
\hline Efekty specjalne & 0,2 & 2,2 & 6,9 & 18,8 & 71,9 & 3,1 & 6,0 & 16,0 & 27,0 & 47,9 \\
\hline Muzyka & 0,2 & 2,2 & 8,3 & 24,2 & 65,1 & 3,7 & 9,0 & 18,6 & 28,6 & 40,1 \\
\hline Promocja filmu & 0,6 & 2,1 & 10,0 & 24,2 & 63,1 & 3,5 & 8,4 & 20,0 & 28,9 & 39,2 \\
\hline Obsada & 0,2 & 2,7 & 10,1 & 24,6 & 62,4 & 4,5 & 10,5 & 19,2 & 25,9 & 39,9 \\
\hline Zdjęcia & 0,3 & 2,1 & 10,1 & 25,1 & 62,4 & 5,4 & 10,4 & 20,0 & 26,5 & 37,7 \\
\hline Reżyseria & 0,1 & 2,2 & 9,3 & 26,7 & 61,7 & 4,5 & 10,9 & 20,3 & 28,6 & 35,7 \\
\hline Scenografia & 0,2 & 2,4 & 9,4 & 27,0 & 61,0 & 5,4 & 12,9 & 20,4 & 26,3 & 35,0 \\
\hline Fabuła/scenariusz & 0,5 & 3,9 & 12,3 & 28,2 & 55,1 & 13,7 & 14,2 & 20,3 & 22,3 & 29,5 \\
\hline Thumaczenie na j. polski & 4,3 & 7,4 & 15,8 & 27,5 & 45,0 & - & - & - & - & - \\
\hline
\end{tabular}

Źródło: badania własne.

W badaniach dokonano oceny polskich i zagranicznych produkcji filmowych. Ocena repertuaru kin w Polsce została przeprowadzona w oparciu o wybrane charakterystyki repertuaru (na siedmiostopniowej skali Likerta, która została zredukowana do skali pięciostopniowej). Badani wyżej ocenili filmy zagraniczne niż polskie. W filmach zagranicznych badani najwyżej ocenili efekty specjalne, a najniżej tłumaczenie na język polski. W polskich filmach badani najwyżej ocenili muzykę, a najniżej efekty specjalne (tab. 3).

\section{Zakończenie}

Każdy konsument usług kinowych stanowi swego rodzaju indywiduum o określonych upodobaniach, dążeniach i pragnieniach. Poznanie postaw i preferencji, które są subiektywnymi ocenami lub systemem ocen, którymi konsument się kieruje, ma duże znaczenie dla przedsiębiorstw usługowych funkcjonujących na rynku kinematografii. Do badania postaw i preferencji widzów kinowych można z powodzeniem stosować skale nominalne i porządkowe. Respondenci nie mają problemów z odpowiedzią na pytania mierzone na takich skalach. Oczywiście pomiar taki ogranicza dopuszczalne operacje matematyczne. Prezentacja wyników badań (w postaci tabelarycznej, graficznej czy konieczności narysowania bardziej zaawansowanych modeli postaw konsumentów) nie sprawia większych trudności. 


\section{Literatura}

Aronson E., Wilson T.D., Akert R.M., 2000, Psychologia spoleczna. Serce i umyst, Wydawnictwo Zysk i S-ka, Poznań.

Bazarnik J., Grabiński T., Kąciak E., Mynarski S., Sagan S., 1992, Badania marketingowe. Metody i oprogramowanie komputerowe, Canadian Consortium of Management Schools, Wydawnictwo Akademii Ekonomicznej w Krakowie, Kraków.

Bąk A., 2013, Mikroekonometryczne metody badania preferencji konsumentów z wykorzystaniem programu R, C.H. Beck, Warszawa,

Begg D., Fischer S., Dornbusch R., 2007, Mikroekonomia, PWE, Warszawa.

Buczyńska T., 2007, Mikroekonomia, Wydawnictwo Szkolne PWN, Warszawa - Łódź.

Centrum Badań i Transferu Wiedzy, 2015, Widz kinowy w Polsce. Raport z badań, Uniwersytet Ekonomiczny w Katowicach, https://www.pisf.pl/aktualnosci/widz-kinowy-w-polsce-raport-z-badan (20.11.2017).

Churchill G.A., 2002, Badania marketingowe. Podstawy metodologiczne, Wydawnictwo Naukowe PWN, Warszawa.

Kaczmarczyk S., 2007, Zastosowanie badań marketingowych. Zarządzanie marketingowe i otoczenie przedsiębiorstwa, PWE, Warszawa.

Karcz K., Kędzior Z., 1999, Postawy konsumentów wobec produktów krajowych i zagranicznych, CBiE AE Katowice, Katowice.

Kowal J., 1998, Metody statystyczne w badaniach sondażowych rynku, Wydawnictwo Naukowe PWN, Warszawa.

Krasiński Z., Piasny J., Szulce H., 1984, Ekonomika konsumpcji, PWE, Warszawa.

Marciniak S. (red.), 2001, Makro i mikroekonomia. Podstawowe problemy, Wydawnictwo Naukowe PWN, Warszawa.

Mika S., 1984, Wstęp do psychologii społecznej, PWN, Warszawa.

Nasiłowski M., 2006, System rynkowy. Podstawy mikro- i makroekonomii, KeyText, Warszawa.

Nowak S. (red.), 1973, Teorie postaw, PWN, Warszawa.

O’Shaughnessy J., 1994, Dlaczego ludzie kupuja, PWE, Warszawa.

Oleksiak A., Białek J., 2008, Mikroekonomia, KeyText, Warszawa.

Oppenheim A.N., 1992, Kwestionariusze, wywiady, pomiary postaw, Zysk i S-ka, Poznań.

Rudnicki L., 2004, Zachowanie rynkowe nabywców. Mechanizmy i uwarunkowania, Wydawnictwo Akademii Ekonomicznej w Krakowie, Kraków.

Sagan A., 2004, Badania marketingowe. Podstawowe kierunki, Wydawnictwo Akademii Ekonomicznej w Krakowie, Kraków.

Sagan A., 2016, Metodologia badań ekonomicznych, Wydawnictwo Uniwersytetu Ekonomicznego w Krakowie, Kraków.

Sobocińska M., 2015, Uwarunkowania i perspektywy rozwoju orientacji rynkowej w podmiotach sfery kultury, Wydawnictwo Uniwersytetu Ekonomicznego we Wrocławiu, Wrocław.

Wiszniewski Z., 1997, Mikroekonomia wspótczesna. Syntetyczne ujęcie, WSBFiZ, CEiRB, Warszawa.

Woś J., Tachocka J., Kasperek-Hoppe M., 2011, Zachowania konsumentów - teoria i praktyka, Wydawnictwo Uniwersytetu Ekonomicznego w Poznaniu, Poznań. 